Latin American Economic Crises

Trade and Labour

This is IEA conference volume no. 136 
This page intentionally left blank 


\section{Latin American Economic Crises}

\section{Trade and Labour}

Edited by

Enrique Bour

Universidad de Buenos Aires, Argentina

Daniel Heymann

Universidad de Buenos Aires, Argentina

and

Fernando Navajas

Universidad de la Plata, Argentina 


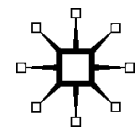

(c) International Economic Association 2004

Softcover reprint of the hardcover 1st edition 2004 978-0-333-99935-6

All rights reserved. No reproduction, copy or transmission of this publication may be made without written permission.

No paragraph of this publication may be reproduced, copied or transmitted save with written permission or in accordance with the provisions of the Copyright, Designs and Patents Act 1988, or under the terms of any licence permitting limited copying issued by the Copyright Licensing Agency, 90 Tottenham Court Road, London W1T 4LP.

Any person who does any unauthorized act in relation to this publication may be liable to criminal prosecution and civil claims for damages.

The authors have asserted their rights to be identified as the authors of this work in accordance with the Copyright, Designs and Patents Act 1988.

First published 2004 by

PALGRAVE MACMILLAN

Houndmills, Basingstoke, Hampshire RG21 6XS and

175 Fifth Avenue, New York, N. Y. 10010

Companies and representatives throughout the world

PALGRAVE MACMILLAN is the global academic imprint of the Palgrave Macmillan division of St. Martin's Press, LLC and of Palgrave Macmillan Ltd. Macmillan ${ }^{\circledR}$ is a registered trademark in the United States, United Kingdom and other countries. Palgrave is a registered trademark in the European Union and other countries.

ISBN 978-1-349-43335-3

ISBN 978-1-4039-4385-9 (eBook)

This book is printed on paper suitable for recycling and made from fully managed and sustained forest sources.

A catalogue record for this book is available from the British Library.

Library of Congress Cataloging-in-Publication Data

Latin America economic crises : trade and labour / edited by Enrique Bour, Daniel Heymann, Fernando Navajas.

p. cm. - (International Economic Association publications) Includes bibliographical references and index.

1. Latin America-Economic conditions-1982-Congresses. 2. Financial crises-Latin America-Congresses. 3. Latin America-Commerce-Congresses. 4. Labor market-Latin America-Congresses. 5. Income distribution-Latin America-Congresses. I. Bour, Enrique. II. Heymann, Daniel. III. Navajas, Fernando. IV. Series.

HC125.L3437 2003

$338.5^{\prime} 42^{\prime} 098-d c 21$

$\begin{array}{rrrrrrrrrr}10 & 9 & 8 & 7 & 6 & 5 & 4 & 3 & 2 & 1\end{array}$

$\begin{array}{llllllllll}13 & 12 & 11 & 10 & 09 & 08 & 07 & 06 & 05 & 04\end{array}$




\section{Contents}

The International Economic Association vii

Preface and Acknowledgements by Jacques Drèze ix

List of Contributors $\quad \mathrm{xi}$

Abbreviations and Acronyms xiii

Introduction by Enrique Bour, Daniel Heymann and $\mathrm{xv}$

Fernando Navajas

\section{Part I Macroeconomic Crises}

1 A Comparison of Currency Crises between Asia and Latin America

Koichi Hamada

2 Latin America and the External Crisis of the Second Half of the 1990s

Vittorio Corbo

3 Banking Crises in Latin America in the 1990s: Lessons from Argentina, Paraguay and Venezuela

Alicia García-Herrero

4 On the Causes of the Latin American and Asian Currency Crises of the 1990s

Marcel Fratzscher

5 Contagion in Emerging Markets: When Wall Street is a Carrier

Guillermo A. Calvo

\section{Part II Trade and Trade Agreements}

6 Preferential Trade Agreements at the Turn of the Century T. N. Srinivasan

7 The Role of Sub-regional Agreements in Latin American Economic Integration

Victor Urquidi 
8 International Specialization and Trade Regimes in Argentina 1960-99

Luis Miotti, Carlos Quenan and Carlos Winograd

9 Testing the Short- and Long-run Exchange-Rate Effects on the Trade Balance: The Case of Colombia

Hernán Rincón

10 External Shocks, Relative Prices and Sectoral

Reallocation in a Small Open Economy: Evidence from Mexico

Talan İşcan

11 Exchange-Rate Movements and the Export of Brazilian Manufactures

Alfonso Ferreira and Andreu Sansó

\section{Part III Labour and Income Distribution}

12 The Impact of Firing Costs on Turnover and Unemployment: Evidence from Colombia Adriana D. Kugler

13 Structural Reform and the Distribution Effects of Price Changes in Argentina 1988-98

Fernando H. Navajas

14 Endogenous Child Mortality, the Price of Childspecific Goods and Fertility Decisions: Evidence from Argentina Alessandro Cigno and Graciela Pinal

15 Child Labour in Peru: An Empirical Analysis and its Modelling Implications

Ranjan Ray 


\section{The International Economic Association}

A non-profit organization with purely scientific aims, the International Economic Association (IEA) was founded in 1950. It is a federation of some 60 national economic associations in all parts of the world. Its basic purpose is the development of economics as an intellectual discipline, recognizing a diversity of problems, systems and values in the world and taking note of methodological diversities.

The IEA has, since its creation, sought to fulfil that purpose by promoting mutual understanding among economists through the organization of scientific meetings and common research programmes, and by means of publications on problems of fundamental as well as current importance. Deriving from its long concern to assure professional contacts between East and West and North and South, the IEA pays special attention to issues of economies in systemic transition and in the course of development. During its 50 years of existence, it has organized more than 100 round-table conferences for specialists on topics ranging from fundamental theories to methods and tools of analysis and major problems of the present-day world. Participation in round tables is at the invitation of a specialist programme committee, but 12 triennial World Congresses have regularly attracted the participation of individual economists from all over the world.

The Association is governed by a Council, comprising representatives of all member associations, and by a 15 -member Executive Committee which is elected by the Council. The Executive Committee (1999-2002) at the time of the Buenos Aires Congress was:

President: $\quad$ Professor Robert Solow, USA

Vice-President: $\quad$ Professor Vittorio Corbo, Chile

Treasurer: $\quad$ Professor Jacob Frenkel, Israel

Past President: $\quad$ Professor Jacques Drèze, Belgium

Other members: $\quad$ Professor Bina Agarwal, India

Professor Maria Augusztinovics, Hungary

Professor Eliana Cardoso, World Bank

Professor Gene Grossman, USA

Professor Seppo Honkapohja, Finland

Professor Valery Makarov, Russia

Professor Andreu Mas Colell, Spain 
Professor Mustapha Nabli, Tunisia

Professor Adrian Pagan, Australia

Professor Hans Werner Sinn, Germany

Professor Kotaro Suzumura, Japan

Secretary-General: Professor Jean-Paul Fitoussi, France

General Editor: $\quad$ Professor Michael Kaser, UK

Sir Austin Robinson was an active Adviser on the publication of IEA Conference proceedings from 1954 until his final short illness in 1993.

The Association has also been fortunate in having secured many outstanding economists to serve as President:

Gottfried Haberler (1950-53), Howard S. Ellis (1953-56), Erik Lindahl (1956-59), E.A.G. Robinson (1959-62), Ugo Papi (1962-65), Paul A. Samuelson (1965-68), Erik Lundberg (1968-71), Fritz Machlup (1971-74), Edmund Malinvaud (1974-77), Shigeto Tsuru (1977-80), Victor L. Urquidi (1980-83), Kenneth J. Arrow (1983-86), Amartya Sen (1986-89), Anthony B. Atkinson (1989-92), Michael Bruno (1992-95) and Jacques Drèze (1995-99).

The activities of the Association are mainly funded from the subscriptions of members and grants from a number of organizations, including continuing support from UNESCO, through the International Social Science Council. Specific support from the latter was received for the Buenos Aires Congress under its Project R4/CAR. 


\section{Preface and Acknowledgements}

The Twelfth World Congress of the International Economic Association (IEA) was held in Buenos Aires on 23-27 August 1999, at the invitation of the Asociación Argentina de Economa Política (AAEP). The IEA is deeply grateful to the AAEP for its willingness to host the congress, and above all for superbly handling the local arrangements. The 1,260 registered participants undoubtedly feel equally grateful.

The congress was dedicated to the memory of the late Michael Bruno, President of the IEA 1992-95, as a tribute to his valuable contributions to economics, and in particular to the IEA.

The Organizing Committee consisted of Enrique Bour, president, Rolf Mantel, vice-president, Victor Beker, executive secretary, Marcela Cristini, Maria Echart, Marcos Gallacher and Javier Ortiz. It is very sad that Rolf Mantel died prematurely in February 1999; he had been a productive researcher and an influential member of the Latin American scientific community. He was an exceptionally fine person. The IEA joins Mrs Mantel and Rolf's numerous friends in treasuring his memory.

Special thanks go to Enrique Bour, former AAEP President, who shouldered much responsibility as president of the Organising Committee. He showed exceptional dedication, ability and congeniality.

Financial support towards the local organization came first from Banco Central de la República Argentina, soon complemented by Banco de la Nacíon Argentina, Banco de la Provincia de Buenos Aires, Banco Hipotecario, Ministerio de Relaciones Exteriores, Comercio Internacional y Culto, Secretaría de Industria, Comercio y Miniera and Secretaría de Programacíon Económica y Regional. Their support is gratefully acknowledged.

The logistics of the congress were handled with competence by the staff of María Graziani y Asociados of Buenos Aires, and by IEA administrative assistants Marie David and Véronique de Labarre.

The scientific programme included two series of invited lectures, one on 'Macroeconomics' organized by Jacques Drèze (Université Catholique de Louvain) and one on 'Inequality' organized by Richard Freeman (Harvard University and London School of Economics). The rest of the programme comprised 310 contributed papers, selected 
from a still larger number of submissions by a 30-member Programme Committee ably and diligently chaired by David de la Croix (Université Catholique de Louvain). From these, 15 important papers dealing with Latin American issues constitute the present volume, edited by Enrique Bour, Daniel Heymann and Fernando Navajas. A major theme of this volume is the exploration of the causes of crises, and the alternative solutions adopted by different Latin American countries. The chapters dealing with Argentina provide an illuminating backdrop to the 2001 financial crisis and help to explain the difficulty of finding a solution that meets the aspirations both of the Argentine people and international institutions. The fifteen chapters are arranged in three Parts: Macroeconomic crises; Trade and Trade Agreements; and Labour and Income Distribution. Maureen Hadfield and Michael Kaser supervised the editorial process. The IEA expresses its gratitude to all participants in their efforts for both programme and publication.

Some hundred authors of invited papers, in particular authors from emerging countries, received travel grants to Buenos Aires. These grants were funded by the World Bank, the World Bank Institute, the InterAmerican Development Bank, the Asian Development Bank and the European Investment Bank. Their support is gratefully acknowledged.

The main credit for the success of the congress goes to the authors of invited lectures and contributed papers. They supplied a rich intellectual material, incompletely but representatively covered in these three volumes. 


\section{List of Contributors}

Professor Enrique Bour, Fundación de Investigaciones Económicas Latino Americanas (FIEL) and Universidad de Buenos Aires, Argentina.

Dr Guillermo A. Calvo, Inter-American Development Bank, Washington and University of Maryland, USA.

Professor Alessandro Cigno, Università di Firenze, Florence, Italy.

Professor Vittorio Corbo, Pontifica Universidad Católica de Chile, Santiago, Chile and Governor, Central Bank of Chile.

Professor Alfonso Ferreira, Universidade Federal de Minais Gerais and Centro de Pesquisa em Economía, Belo Horizonte, Brazil.

Professor Marcel Fratzscher, European Central Bank, Frankfurt am Main, Germany.

Dr Alicia García-Herrero, Banco Central de España, Madrid, Spain.

Professor Koichi Hamada, Yale University, New Haven, Connecticut, USA.

Professor Daniel Heymann, Universidad de Buenos Aires and La Plata, Argentina.

Professor Talan İşcan, Dalhousie University, Halifax, Nova Scotia, Canada.

Professor Adriana Kugler, Universitat Pompeu Fabra, Barcelona, Spain.

Professor Luis Miotti, Université de Paris 13, Paris, France.

Proessor Fernando Navajas, Fundación de Investigaciones Económicas Latino Americanas (FIEL), Buenos Aires and Universitá de la Plata, Argentina.

Dr Graciela Pinal, Universidad Nacional di Salta, Salta, Argentina.

Professor Carlos Quenan, CREDAL, Universíté de Paris 3, Paris, France.

Professor Ranjan Ray, University of Tasmania, Hobart, Australia. 
Professor Hernán Rincón, Banco de la República, Bogotá, Colombia. Professor Andreu Sansó, Universitat de Barcelona, Spain.

Professor T. N. Srinivasan, Yale University. New Haven, Connecticut, USA.

Professor Victor Urquidi, El Colegio di México, Mexico City.

Professor Carlos Winograd, Delta-Ens and Université de Paris-Evry, Paris, France. 


\section{Abbreviations and Acronyms}

$\begin{array}{ll}\text { AA } & \text { absorption approach } \\ \text { ADF } & \text { augmented Dickey-Fuller (test) } \\ \text { ADM } & \text { anti-dumping measure } \\ \text { ALADI } & \text { Latin American Integration Association } \\ \text { BIS } & \text { Bank for International Settlements } \\ \text { BRM } & \text { Bickerdike, Robinson, Metzler (model) } \\ \text { CA } & \text { current account } \\ \text { CARICOM } & \text { Caribbean Community and Common Market } \\ \text { CARIFTA } & \text { Caribbean Free Trade Area } \\ \text { CBP } & \text { Central Bank of Paraguay } \\ \text { CBRA } & \text { Central Bank of Republica Argentina } \\ \text { CBV } & \text { Central Bank of Venezuela } \\ \text { CPI } & \text { consumer price index } \\ \text { CTP-Data } & \text { Comparative Trade Performances Data Base } \\ \text { DOTS } & \text { Direction of Trade Statistics } \\ \text { DP } & \text { Dickey and Pantula (procedure) } \\ \text { DSM } & \text { dispute settlement mechanism } \\ \text { ECLAC } & \text { UN Economic Commission for Latin America and the } \\ & \text { Caribbean (CEPAL in Spanish) } \\ \text { EMBI } & \text { emerging markets bonds index } \\ \text { ERP } & \text { effective rates of protection } \\ \text { ESI } & \text { economies of scale-intensive (goods) } \\ \text { EU } & \text { European Union } \\ \text { FOGADE } & \text { Deposit Guarantee Fund (Venezuela) } \\ \text { FIEL } & \text { Fundación de Investigaciones Económicas } \\ & \text { Latinoamericanas } \\ \text { GATT } & \text { General Agreement on Tariffs and Trade } \\ \text { GDP } & \text { gross domestic product } \\ \text { GSP } & \text { generalized system of preferences } \\ \text { HES } & \text { household expenditure survey } \\ \text { HIID } & \text { Harvard Institute of International Development } \\ \text { HOS } & \text { Hecksher-Ohlin-Samuelson } \\ \text { IDB } & \text { Inter-American Development Bank } \\ \text { IFS } & \text { International Financial Statistics } \\ \text { i.i.d. } & \text { independently and identically distributed } \\ \text { ILO } & \text { International Labour Organization } \\ & \end{array}$




\begin{tabular}{|c|c|}
\hline IMF & International Monetary Fund \\
\hline INDEC & $\begin{array}{l}\text { Instituto Nacional de Estadística y Censos (National } \\
\text { Institute of Statistics and the Census) }\end{array}$ \\
\hline INEGI & $\begin{array}{l}\text { Instituto Nacional de Estadística, Geografía y } \\
\text { Informatíca (Mexico) }\end{array}$ \\
\hline ISS & import substituting strategies \\
\hline LAFTA & Latin American Free Trade Area \\
\hline LDC & less-developed countries \\
\hline LLR & lender of last resort \\
\hline LSMS & Living Standards Measurement Study \\
\hline MA & monetary approach \\
\hline Mercosur & South American Regional Organization \\
\hline MFN & most-favoured nation \\
\hline MFT & more-favourable treatment \\
\hline ML & Marshall-Lerner \\
\hline MTN & multilateral trade negotiations \\
\hline NSC & no-shirking condition (Colombia) \\
\hline NAFTA & North American Free Trade Agreement \\
\hline NHS & National Household Survey (Colombia) \\
\hline OECD & $\begin{array}{l}\text { Organisation for Economic Co-operation and } \\
\text { Development }\end{array}$ \\
\hline PLSS & Peru Living Standards Measurement Survey \\
\hline PTA & preferential trading agreement \\
\hline R\&D & research and development \\
\hline RCA & revealed comparative advantage \\
\hline RER & real exchange rate \\
\hline REER & real effective exchange rate \\
\hline ROME & Research Opportunity in Mathematics and Economics \\
\hline ROW & rest of the world \\
\hline SP & Schmidt-Phillips (test) \\
\hline TL & Trade liberalization \\
\hline TRIMS & trade-related investment measures \\
\hline TRIPS & trade-related (aspects of) intellectual property rights \\
\hline UNCTAD & United Nations Conference on Trade and Development \\
\hline UR & Uruguay Round \\
\hline WIPO & World Intellectual Property Organization \\
\hline WTO & World Trade Organization \\
\hline
\end{tabular}




\title{
Introduction
}

\author{
Enrique Bour, Daniel Heymann and Fernando Navajas
}

This volume on Latin America focuses on studies of economic crises during the 1990s. While the authors completed their research before the 2001 crisis in Argentina, the analyses of macroeconomic issues provide an insight into how economies can break down and even degenerate into chaotic behaviour, while the chapters on Argentina help to provide an understanding of recent events there.

\section{Macroeconomic crises}

The five chapters in Part I concentrate on financial crises. Latin American economies have long experience of sudden breakdowns of currency pegs, widespread bank failures or abrupt declines in spending and output. Interest in studying crisis episodes surged recently as new crises generated new analytical problems for study. The authors use different approaches to analyse recent Latin American and Asian experience, and draw conclusions relevant to the management of large macroeconomic disturbances.

Koichi Hamada, in Chapter 1, first examines Asian crises and associates crisis events with misjudgments in economic calculations. He observes that in high-saving, high-investment Asian economies, a rapid growth generated highly optimistic expectations on the part of local agents and foreign lenders, and that 'disillusionment triggered the crisis in these overconfident economies'. Significantly, Hamada's argument does not depend on 'bad' current indicators before a crisis, but only on the perception of future prospects being revised downwards. Hamada cites real-estate investment in Asian cities based on unrealistic forecasts. He argues that the belief by market participants that they have been overoptimistic can trigger a sudden fall in the demand for a country's assets. Turning to Latin America, Hamada observes that, while in Asia most of the foreign debt was owed by the private sector, in Latin America it was owed by governments, and he highlights weaknesses in fiscal and monetary policies, which could precipate a crisis.

Vittorio Corbo in Chapter 2 presents a broad overview of the response of Latin American economies to the shocks that hit the region in the late 1990s. Corbo identifies several disturbances which 
resulted in a sharp drop in export prices and tighter conditions of access to foreign financing. He argues that the policy reforms undertaken by many countries in the 1990s, including measures such as strengthening bank regulations after the 1994-5 crisis, helped these economies deal with shocks. They were also able to avoid imposing trade restrictions or expanding domestic demand to compensate for external shocks. His data show that in 1999, growth in the region had virtually stopped; indeed, growth in several countries (including Chile after over a decade of growth) contracted.

Corbo concentrates on monetary and exchange-rate systems. He discusses inflation targeting, which several countries defined as their preferred monetary framework, pointing out potential benefits and possible problems such as output or exchange-rate volatility. In discussing exchange-rate regimes, the advantages of floating are stressed, and he notes that the countries that suffered severe crises in the 1990s all operated some form of fixed exchange rate. However, Corbo observes that in practice 'strong path dependence is the rule' in the choice of system, given that the trade-offs would have different outcomes depending on past economic history.

In her study of three Latin American banking crises, Alicia GarcíaHerrero (Chapter 3) suggests that the macroeconomic consequences of a crisis and the range of policy options may be influenced by features of the financial sector and the nature of the problems. García-Herrero identifies distortions in the behaviour of banks in a system without adequate supervision as a major cause of the Paraguay crisis. In Venezuela, inadequate regulation and control and a weak oil market caused macroeconomic tensions and a distrust of government policies. In Argentina, the author identifies the origin of the crisis in 1997 in the provincial banking sector. The situation was exacerbated by the effects of the Mexican shock on an economy with persistent currentaccount deficits and a worsening fiscal situation.

The remaining two chapters in this section are devoted to models of crises. In Chapter 4, Marcel Fratzscher presents a model of financial crises. He considers the hypothesis that currency crises result from selffulfilling expectations driven by an external event. He proposes a model with multiple equilibria which do not result from government incentives (as in the case where, for example, expectations of a currency devaluation lead to high interest rates on debt, and induce the authorities to devalue rather than raise taxes). In Fratzscher's argument, initial government reserves are fixed, and fully available to defend a peg. The demand for foreign currencies originates from 
different sources: producers who buy imports and pay debt service; foreign creditors who choose whether to refinance or recall the debt. Then there is a set of speculators with limited resources, who attack the currency when they anticipate a devaluation. Multiple equilibria arise if the 'fundamental demand' for foreign currencies is such that reserves will not be exhausted when creditors refinance and speculators do not attack, but do not sustain a credit stop and/or a move by speculators.

The author uses regime-switching models to analyse empirically the transmission of the crises in Mexico (1994) and Thailand (1997). Fratzscher remarks that the assumption that changes in the intercept of a regression represent shifts due to beliefs unrelated to fundamentals ignores the possibility that those changes represent fundamentals unaccounted for, or expectations about fundamentals. In order to include variables that he interprets specifically as 'sunspots', the author uses dummies for crises occurring in other economies. This model of exchange-market pressure considers a number of fundamental explanatory variables (such as foreign debt and capital-flow indicators, trade balances, real exchange rates, reserves, credit expansion and the budget deficit). Fratzscher observes that in most cases a specification with three regimes is appropriate. He also finds that crisis dummies are significant, and argues that this provides evidence for sunspot phenomena, although contagion effects may arise from a variety of sources.

Guillermo Calvo's analysis (Chapter 5) is inspired by the contagion effects of the Russian crisis, which had strong repercussions in Latin America. The basic assumption is that prospective asset-holders face large fixed costs (relative to the funds they are prepared to invest in) in obtaining knowledge about the economy whose debt they consider buying. The argument does not specify if the costs result from a nonzero price of raw data, or from difficulties in interpreting information, which would imply that the 'model of the economy' is subject to learning. Calvo notes that fixed costs create economies of scale, and agents will be divided into two groups: those who will pay to be 'informed', and those who base decisions on the market price, and the inferences drawn from observing the actions of the informed investors.

Calvo considers the case where the demand for a country's assets by the informed group depends on the conditions of that economy and factors unrelated to those conditions (such as the liquidity position of the agents). The model assumes that the idiosyncratic factors are common to all informed agents (although the consequences of lifting that assumption are discussed). The 'non-informed' face a signal- 
extraction problem, and may react strongly to the behaviour of the influential segment of investors when there are no 'fundamental reasons' to do so. Since the uninformed agents will tend to follow more closely the actions of the informed the smaller the variance of the idiosyncratic factors, episodes with large contagion effects of this type would be relatively infrequent. However, Calvo argues that the resulting shocks may have a strong impact on the borrowing economy, especially if these are amplified by a fall in the productivity of capital as a consequence of the sudden contraction of international credit.

These chapters - a sample of a large and growing literature on crisis economics - indicate an active search for better analytical and practical solutions. This implies that analysts are engaged in learning about the origins and mechanisms of crises and in searching for appropriate policies to reduce their occurrence, and limit adverse macroeconomic consequences. It seems natural to assume that private agents have also been trying to learn from large disturbances. This observation is relevant to any discussion of how to represent expectations in economic models of those events.

\section{Trade and trade agreements}

In Chapter 6, T. N. Srinivasan argues strongly for free trade, and criticizes several points of the theory of international trade negotiations. Srinivasan argues against propositions that viewed a managed international market and discriminatory trade arrangements as a good way to close the 'foreign exchange gap' at GATT discussions. He considers that the attitudes of developing countries were driven by 'import-substitution ideology', which 'triply hurt them': first, through the costs of import substitution strategies; second, by allowing developed countries to get away with their own GATT-inconsistent barriers; and, third, by allowing industrialized countries to keep higher than average 'mostfavoured-nation' tariffs on goods of export interest to developing countries. He concludes that had these countries adopted an outwardoriented development strategy, they could have achieved 'faster and better growth'.

From the perspective of developing countries, Srinivasan proposes a new agenda for the next round of trade negotiations under which intellectual property and related concerns would be negotiated at the World Intellectual Property Organization, not the World Trade Organization. The author argues for rapid negotiation on the movement of natural persons, the elimination of export subsidies by 
developed nations, and the removal of anti-dumping measures from the arsenal of permitted trade-policy instruments. Srinivasan also proposes the elimination of practices such as peaks in tariffs and the escalation in tariffs by stages, which restrict the exports of developing countries. The author suggests replacing GATT Article XXIV by extending preferences granted to a partner of a preferential trade agreement to all members of the World Trade Organization within a specified period. The proposals presented by Srinivasan also include abstaining from negotiating a multilateral agreement on investment for the present, and correcting flaws in the Dispute Settlement Mechanism.

Victor Urquidi (Chapter 7) disputes the notion that the whole of Latin America should seek economic integration. In a discussion that reviews the history of integration projects, he sees full economic integration between highly dissimilar countries as unrealistic in today's globalized economy. Instead, he recommends limited sub-regional agreements. Pointing to the trade-creation role of investment, he foresees clusters of suppliers emerging through sub-regional integration. Urquidi expects the development of horizontal integration more similar to existing arrangements among industries in industrialized countries. To enable the lesser economies to acquire the necessary skills, he recognizes the need for substantial long-term financing and technological and management support. This would constitute a new role for Mercosur and other international entities.

In Chapter 8, major shifts in the composition of external trade are analysed by Miotti, Quenan and Winograd with reference to Argentina and Mercosur. They reexamine the theories of comparative advantage, technological development and the dynamics of international markets, highlighting the pattern of capital goods, energy and labour. They view these theories as complementary. They identify successive phases of protection and trade liberalization, separated by crises which triggered regime shifts. The authors conclude that trade liberalization is not always accompanied by rapid export growth, as suggested by simple economic theory.

Conventional wisdom argues that nominal devaluations entail an improvement in the trade balance. Rincón (Chapter 9) tested this proposition for Colombia, using a model that incorporates the effects of income and money. He found that the behaviour of the exchange rate and the trade balance conforms to the traditional analysis of authors Bickerdike, Robinson, Metzler, Marshall and Lerner under the 'small-country' hypothesis. The econometric procedure is based on the analysis of multivariate cointegrated systems developed by Johansen 
and expanded by Johansen and Juselius. One conclusion is that besides varying with the exchange rate, the trade balance responds to decreases in the money stock and increases in income.

Although the experience of nominal devaluations has certainly been traumatic in Latin America, Talan İscan, in Chapter 10, explores the potential benefits of these policy measures. A key parameter of trade models is the elasticity of substitution between the consumption of tradable and non-tradable goods. He finds that the reallocation of factors between sectors has been one of the more important consequences of real devaluations in Mexico. Using cross-section and time series for Mexico, the extent to which the real exchange rates and the terms of trade have been conducive to reallocation in the Mexican production sector are examined and a pattern of diverse behaviour is revealed. However, the analysis finds significant sectoral output effects of terms-of-trade shocks and real-exchange movements. Improvements in Mexican terms of trade tend to be associated with a relative expansion in the output of non-traded goods, while depreciation of the Mexican peso correlates with contractions in that sector. The author concludes that, in Mexico, the elasticity of substitution in consumption between traded and non-traded goods seems to be lower than 1 . As to the effects of real exchange-rate movements, Iscan notes that the response of a dynamic output regression model using a random coefficient regression technique suggests that relative price effects on sectoral output were highly significant. The short-run contractionary effects of currency devaluations appeared to be temporary. The author concludes that devaluations in Mexico increased the trade balance by changing relative prices.

Afonso Ferreira and Andreu Sansó (Chapter 11) produce evidence that exchange-rate variations were not substantially reflected in the selling prices of Brazilian exported goods, and argue that this limited the success of the exchange-rate policy. They analyse the 'exchange pass-through' coefficient in the equation of external prices of Brazilian manufactured goods; that is, the coefficient which relates a variation of the exchange rate to a variation of the foreign currency price. They calculate its range between 10 per cent and 27 per cent. They argue that the reason for this relatively small coefficient is that to preserve market share, exporters maintain prices in foreign currencies when exchange rates are perceived as transitory. They suggest that the coefficient depends on the behaviour of the exchange rate itself, with periods of exchange-rate instability being reflected in low pass-through coefficients. More generally, their 
results validate the 'small country' hypothesis for Brazil, implying that in times of domestic currency appreciation, exporters' profit margins tend to be squeezed, possibly to the point of eliminating all incentive to sell abroad.

\section{Employment and income distribution}

The final section deals with labour issues and income distribution. These topics have been at the top of the policy and research agenda during the 1990s, particularly in Latin America. Deregulation of domestic markets, trade liberalization, large-scale privatizations and labour-market reforms are major examples of policies which changed the configuration and the behaviour of Latin American economies. However, with few exceptions, well-designed policies to deal with social problems have lagged behind. The analysis of changes in employment and income distribution and the evaluation of relevant policies are ongoing processes. The chapters by Adriana Kugler and Fernando Navajas discuss matters relating to structural reform and macro-policy. Those by Ranjan Ray and Alessandro Cigno and Graciela Pinal look, respectively, at household allocation and labour participation, and the impact on children.

Chapter 12 by Adriana Kugler contributes to the literature on job security regulations on labour-market performance. She studies empirically the effects of a major Colombian labour reform. The relaxation of job security regulations often recommended in Latin America and elsewhere to improve the quality of employment and reduce unemployment has been controversial. The theoretical analysis of the net effects of hiring and firing on employment and unemployment during the 1990s produced ambiguous qualitative results, which were not resolved by empirical testing. Kugler tries to improve on previous testing methods by avoiding the selection-bias problems that may have influenced the econometric results of pooled time-series and crosssection data models. She develops a model to explain how job security provisions induce selection bias and tackles the compositional changes between formal and informal workers - a relevant dimension in Latin American economies - on grouping estimates. The empirical testing focuses on the Colombian Labour-market Reform Act of 1990 using National Household Survey data. The results show that after controlling for compositional change, the relaxation of job security regulations appear to contribute to reducing unemployment. Kugler concludes that labour reform in Colombia induced efficiency gains 
through greater mobility, and welfare gains from lower unemployment and the formalization of the economy.

In Latin America, Argentina was one of the more prominent economic reformers during the 1990s. As a result, major changes took place in the organization of economic activities and government participation in public services. Fernando Navajas (Chapter 13) extends the methodology used by Newbery for Hungary and the UK, to evaluate the distributional effects of relative price changes after a decade of structural reform. The model is developed from the theory and measurement of marginal tax reform, and relies on the concept of the distributional characteristics of goods. Using data from household expenditure surveys and the price movements of detailed items in the consumer price index, the chapter evaluates the overall welfare change for different degrees of inequality-aversion. It also attempts to decompose the causes of the observed aggregate changes in welfare. The main finding is that, in Argentina, reforms induced relative price changes leading to social welfare gains and positive distributional effects. This is explained by the reduction in the relative price of goods with high distributional characteristics such as clothing, food, durable goods and to a lesser degree some public services. Thus, despite an increase in income inequality, arising from higher unemployment or larger wage dispersion, price changes associated with reforms did not themselves harm the poor. Positive distributional impacts can be attributed to measures such as trade reform and retail competition. Results were less clear for privatizations, because of increases in public-sector prices in recent years. However, other aspects of the distributional effects of privatization, such as changes in the access of the poor to public infrastructure services, were positive.

In Chapter 14, Alessandro Cigno and Graciela Pinal extend an earlier model by Cigno on the interaction between child mortality and fertility decisions, to calculate the effects of the prices of child-specific goods. In this model, household allocation under uncertainty about children's survival jointly determine fertility and infant mortality. According to their hypothesis of endogenous survival probability, parents know the effects of their resource-spending and fertility decisions on child survival probabilities, and react to changes in the observed aggregate survival rate on which they base their expectations. The marginal benefits of resources spent on children, as perceived by their parents, are increased by public spending programmes that raise the aggregate survival rate, and by any fall in the price of child-specific goods. Thus, complementarity between public and private spending 
reinforces the social productivity of public expenditure in sanitation, preventive medicine and subsidies to child-specific goods. The authors test the positive implications of the model on time-series data collected from the province of Salta, in northern Argentina, during the last quarter of the twentieth century. They find that fertility decisions are negatively affected by the observed survival rate and positively affected by the price of child-specific goods in a way consistent with the predictions of their model.

The interaction of poverty and child labour has generated much interest in research and policy-oriented debate. In particular, given the undesirable consequences of child labour, child labour and the identification of factors that affect child employment have become an area of study. A common theme in the development literature, although it seems to apply specifically to rural areas, is the hypothesis that child-labour participation rises in response to temporary income short-falls in the presence of credit rationing. In more general terms, this analysis looks for links between household income, poverty and child labour. Empirical testing of these factors has increased in recent years.

In the final chapter, Ranjan Ray contributes to this study using the Peru Living Standards Measurement Survey for 1994, obtained from the World Bank Living Standards Measurement Study. Using probit and tobit estimation procedures, he tests the determinants of childlabour participation and child-labour hours, taking into account the interaction with participation in schooling, and the effects of adult male and female wages. In contrast to findings for other developing economies, such as Pakistan, the main result is that the case of Peru does not support any relation between poverty and child labour, but suggests an interaction with school provision. The effects of male and female wages on child-labour participation differ widely, but the gender channel of interaction and the magnitude of the coefficients (which are different from those obtained for Ghana) lead to ambivalent conclusions. 